\title{
PENGARUH MODAL KERJA, PERPUTARAN PIUTANG DAN PERPUTARAN PERSEDIAAN TERHADAP PROFITABILITAS PADA PERUSAHAAN PT.MANDIRI MART
}

\author{
Muhammad Rinjani; Kardi \\ Institut Agama Islam Abdullah Said Batam \\ Email : Mhdrinjani9@gmail.com; k412d1e.81@gmail.com
}

\begin{abstract}
Abstrak
Penelitian ini dilakukan untuk melakukan pengujian terhadap pengaruh variabel Modal Kerja, Perputaran Piutang, Perputaran Persediaan terhadap Profitabilitas Pada Perusahaan PT.Mandiri Mart di Batan periode 2020. Popolasi dalam penelitian ini sejumlah 56 perusahaan dagang yang terdapat diBatam. Teknik sampling atau sampel adalah 30 perusahaan. Data diperoleh dari laporan keuangan perusahaan dan wawancara kepada pihak manajemen perusahaan. Hasil penelitian ini menunjukkan bahwa secara simultan variabel modal kerja, perputaran piutang dan perputaran persediaan berpengaruh siqnifikan terhadap profitabilitas. Demikian juga hasil penelitian yang dilakukan secara parsial menunjukkan bahwa variabel modal kerja , perputaran piutang dan perputaran persediaan berpengaruh signifikan terhadap profitabilitas
\end{abstract}

Key words: Modal Kerja; Perputaran piutang dan persediaan; profitabilitas perusahaan.

\section{PENDAHULUAN}

Pada era globalisisi perusahaan pada umumnya adalah untuk memperoleh laba, dengan meningkatkan penjualan, dan meningkatkan kesejahteraan pemegang saham. Persaingan bisnis yang ketat seiring dengan perkembangan perekonomian mengakibatkan adanya tuntutan bagi perusahaan untuk terus mengembangkan inovasi, memperbaiki kinerjanya, dan melakukan perluasan usaha agar terus dapat bertahan dan bersaing.

Meningkatnya profitabilitas suatu perusahaan merupakan suatu keberhasilan dari kinerja perusahaan tersebut sehingga akan meningkatkan kesejahteraan para pemilik perusahaan dan pemegang saham. Profitabilitas perusahaan yang tinggi akan memacu para investor untuk menanamkan modal pada perusahaan tersebut karena dengan tingat profitabilitas yang tinggi akan menyebabkan peminat saham dalam perusahaan yang tinggi juga. Semakin tinggi permintaan saham perusahaan maka semakin tinggi harga saham perusahaan di pasar modal sehingga akan mempengaruhi nilai perusahaannya.

Profitabilitas merupakan alat yang digunakan untuk menganalisis kinerja manajemen, tingkat profitabilitas akan menggambarkan posisi laba perusahaan. Profitabilitas suatu perusahaan akan mempengaruhi kebijakan para investor atas investasi yang dilakukan. Analisis kemampuan perusahaan untuk menghasilkan profit dibutuhkan untuk memastikan pertumbuhan jangka panjang dan kelangsungan hidup perusahaan harus berada dalam keadaan menguntungkan. Perbutaran piutang merupakan elemen modal yang selalu berputar terus menerus rantai perputaran profitabilitas merupakan rasio yang mngukur sejauh mana kemampuan perusahaan menghasilkan penjulan, yaitu dari penjualan secara kredit sehinngga menimbulkan adanya piutang, yang apabila piutang tersebut dibayar oleh konsumen maka secara otomatis akan mejadi kas.

Salah satu upaya yang sering dilakukan oleh perusahaan dalm 


\section{JQIM}

meningkatkan penjualan agar kegiatan usahanya dapat mencapai tingkat keuntungan yang optimal adalah dengan melakukan penjualan secara kredit kepada para pembeli atau pelanggan. Dari penjualan kredit tersebutlah yang akan menyebabkan timbulnya perkiraan piutang pada pihak perusahaan. Resiko tidak diterimanya sebagian piutang merupakan resiko yang dapat menyebabkan berkurangnya pendapatan perusahaan, bahkan bisa menimbulkan kerugian, jika jumlah piutang kurang dari yang seharusnya atau kurang dari harga pokok barang yang dijual secara kredit. Tentu saja perusahaan tidak akan medapatkan laba dari hasil pendapatan yang berkurang.

Sedangkan resiko tertanamnya modal kerja dalam piutang merupakan resiko yang terjadi karena rendahnya tingkan perputaran piutang, sehingga modal kerja yang ditanam dalam piutang terlalu besar dan mengakibatkan adanya modal kerja yang tidak produktif yang akan mengakibatkan kinerja perusahaan menjadi menurun.

Piutang terjadi karena adanya penjualan secara kredit, banyak perusahaan yang menjual barang dagang atau jasa mereka secara kredit, karena penjualan secara kredit tersebut upaya untuk meningkatkan penjualan perusahaan atau untuk mencegah penurunan penjualan. Dengan penjualan secara kredit meningkat maka piutangpun meningkat dan diharapkan laba juga meningkat.

Persediaan memiliki peran yang penting dalam perusahaan dagang maupun perusahaan manufaktur, salah satu alasan dari hal tersebut adalah karena perusahaan dalam hal untuk mencapai tujuan utamanya, perusahaan harus memilki persediaan yang cukup untuk memenuhi kebutuhan pelanggan agar dapat meningkatkan penjualan. Perputaran persediaan digunakan untuk mengetahui kemampuan perusahaan dalam mengelola persediaan, dalam arti apabila persediaan yang ada akan dipenjualan. Semakin tinggi rasio ini, maka semakin cepat perputaran persediaan yang akan dijual penjualan.

Persediaan merupakan salah satu elemen penting yang selalu dalam keadaan berputar. Dalam penentuan besarnya persediaan haruslah seimbang dengan kebutuhan, sebab apabila jumlah persediaan terlalu besar dibandingkan kebetuhannya maka dapat memperbesar kemungkinan terjadinya kerusakan, turunnya kualitas juga menabah biaya guna pemeliharaan dan penyimpanan persediaan. Sebaikanya apabila jumlah persediaan terlalu kecil, maka akan menghambat proses produksi perusahaan sehingga tidak dapat menghasilkan barang yang optimal.

Demikian pula sebaliknya, adanya investasi yang terlalu kecil dalam persediaan akan mempunyai efek yang menekan keuntungan yang mana investasi terlalu kecil akan menyebabkan kekurangan material sehingga perusahan akan mengalami kendala lama produksinya, yang akan mengakibatkan perusahaan tidak akan bisa bekerja dengan kapasitas penuh.

Kenibajak dividen merupakan keputusan yang diambil perusahaan agar dapat menentukan berapa besar bagian dari laba yang diperoleh perusahaan untuk dibagikan sebagian dividen atau sebagian laba ditahan, dan juga kebijakan dividen merupakan sebagian dari keputusan investasi, kebijakan dividen juga berhubungan dengan pembagian pendapatan antara penggunaan pendapatan untuk digunakan pada pemegan saham sebagai dividen atau digunakan dalam perusahaan, dan kebijakan dividen merupakan suatu kebijakan untuk menetapkan pembagian laba bersih yang akan dibagikan kepada pemegang saham dan berapa besar bagian dari laba yang diinvestasikan kembali sebagai laba ditahan.

Pembayaran dividen tidak akan menimbulkan masalah selagi tidak 
mempengaruhi kebijakan pendanaan dalam investasi perushaan, kemampuan perusahaan dalam menghasilkan laba akan membuat daya tarik para investor untuk menanamkan modalnya dalam perusahaan sedangkan bagi perusaan yang profitabilitas dapat digunakan sebagai evaluasi atau pengelolaan bada usaha atau perusahaaan, profitabilitas perusahaan merupakan salah satu dasar penilain kondisi dari sutau perusahaan tersebut dan oleh karena itu dibutuhkan alat untuk menganalisis agar dapat menilainya, yang mana alat analisis yang digunakan ialah rasio keuangan., rasio profitabilitas mengukur efektifitas manajemen berdasarkan hasil pengambalian yang diperoleh dari penjualan dan investasi.

Tujuan utama didirikan suatu organisasi bisnis adalah untuk memproleh laba atau keuntungan yang maksimal dari kegiatan usahanya. Dengan memperoleh laba yang maksimal seperti yang telah ditergetkan, perusahaan dapat melakukan investasi baru, meningkatkan kesejahteraan pemilik dan karyawan perusahaan, serta meningkat mutu produk.

Oleh karena itu manajemen prusahaan dalam prakteknya dituntut harus mampu untuk memenuhi target yang telah ditetapkan, artinya besarnya keuntungan haruslah dicapai sesuai dengan yang diharapkan bukan berarti asal untung. Untuk mengukur tingkat keuntungan suatu perusahaan, digunakan rasio keuntungan atau rasio profitabilitas yang dikenal juga dengan rentabilitas. Penelitian ini dilakukan pada perusahaan manufaktur sektor industri barang konsumsi dikarenakan sektor industri barang konsumsi lebih stabil dan tidak terpengaruh oleh musim ataupun perubahan kondisi prekonomian. Walaupun terjadi krisis ekonomi, kelancaran produksi industri barang (seperti makanan dan minumanan) masih terjamin, karena kondisi apapun konsumen tetap membutuhkan produk

\section{JQIM}

barang-barang konsumsi. Selain itu, Perusahaan manufaktur sektor industri barang konsumsi juga merupakan perusahaan manufaktur yang mempunyai karakteristik pada modal, dan merupakan sektor ekonomi yang paling banyak menyerap dana dari masyarakat, memegang peranan penting dalam pertumbuhan ekonomi

\section{METODE}

\section{Wilayah Penelitian}

Rencana Wilayah Penelitian dilakukan di Perusahaan Dagang PT. Mandiri Mart Batam

\section{Objek Penelitian}

Variabel-variabel yang akan dianalisis dalam penelitian ini adalah oksogen (variabel bebass) yaitu perputaran Modal kerja X1, Perputaran Piutang X2, Perputaran Persediaan X3, Terhadap variable profitabilitas Y.

\section{Jadwal Penelitian}

Pelaksanaan penelitian ini direncanakan dimulai pada 2020 di perusahaan PT.Mandiri Mart.

\section{Kerangka Pemikiran}

Variabel dependen dalam penelitian ini adalah Profitabilitas. Variabel independen dalam penelitian ini adalah Perputaran Modal Kerja, Perputaran Piutang, dan Perputaran Persediaan.

\section{Hipotesis}

Hipotesis dalam penelitian ini dirumuskan sebagai berikut:

$\begin{aligned} \mathrm{H}_{1} \text { : } & \begin{array}{c}\text { Perputaran Modal Kerja } \\ \text { berpengaruh positif signifikan } \\ \text { terhadap profitabilitas. }\end{array}\end{aligned}$

$\mathrm{H}_{2}$ : $\quad$ Perputaran Piutang berpengaruh positif signifikan terhadap profitabilitas.

H3: Perputaran persediaan berpengaruh positif signifikan terhadap profitabilitas

\section{Definis Perputaran profitabilitas}

Profitabilitas merupakan salah satu pengukuran bagi kinerja suatu perusahaan, profitabilitas suatu perusahaan menunjukan kemampuan 
suatu perusahaan dalam menghasilkan laba selama pereode tertentu pada tingkat penjualan, asset dan modal saham tertentu. Profitabilitas suatu perusahaan dapat dinilai melalui berbagai cara tergantung pada laba dan aktiva atau modal yang akan diperbandingkan satu dengan lainya.

Harahap, 2010:226). Committee on terminology mendefinisikan profitabilitas merupakan jumlah yang berasal dari pengurangan harga pokok produksi, biaya lain dan kerugian dari penghasilan atau penghasilan operasi. Profitabilitas adalah ukuran pokok untuk keseluruhan keberhasilan perusahaan

Menurut Greuning 2005:29 profitabilitas adalah suatu indikasi atas bagaimana margin laba suatu perusahaan berhubungan dengan penjualan, modal rata-rata, dan ekuitas saham biasa ratarata.

Menurut fahmi $2015 \quad ; 165$ profitabilitas digunakan untuk mengukur efektifitas manajemen secara keseluruan yang ditujukan oleh besar kecilnya tingkat keuntungan yang diperoleh dalam hubungan dengan penjualan maupun investasi. Semakin baik profitabilitas maka semakin baik menggambarkan kemampuan tingkat memperoleh keuntungan perusahaan.

Menurut kamsim 2015:115 profitabilitas merupakan rasio yang dapat digunakan untuk menilai kemampuan suatu perusahaan dalam mencar keuntungan. Rasio ini juga memberikan ukuran tinggi efektifitas manajemen suatu perusahaan. Hal ini ditungjukan oleh laba yang dihasilkan dari penjualan dan pendapatan investasi.

Beberapa definisi tersebut menyimpulkan bahwa profitabilitas adalah pengukuran kinerja perusahaan yang menunjukkan kemampuan suatu perusahaan dalam menghasilkan laba yang merupakan tolak ukur bagi keberhasilan suatu perusahaan seperti jumlah yang berasal dari pengurangan harga pokok produksi, biaya lain dan kerugian dari penghasilan atau penghasilan operasi.

$$
\text { ROI }=\frac{\text { Laba Bersih Setelah Pajak }}{\text { Total Aktiva }}
$$

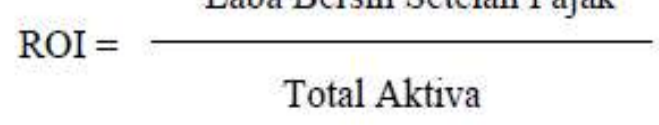

Table 1. Variables Measurement

\begin{tabular}{lc}
\hline \multicolumn{1}{c}{ Variable } & Measurement \\
\hline $\begin{array}{l}\text { Dependent Variable } \\
\text { Good Public Govemance (GPG) }\end{array}$ & $\begin{array}{l}\text { Good Public Govemance Index from five govemance } \\
\text { pinciples using Pinciple Component Analysis }\end{array}$ \\
\hline
\end{tabular}

\section{PEMBAHASAN}

Pengujian Bagian Uji Asumsi Klasik Hasil uji asumsi klasik diketahui bahwa data bebas dari multikolinearitas, bebas heteroskedastisitas, bebas autokorelasi dan data terdistribusi normal. Kemudian dilakukan analisis deskriptif masing-masing variabel pada tabel 1 .

\begin{tabular}{lccccc}
\hline Variabel & N & Minimum & Maximum & Mean & $\begin{array}{l}\text { std. } \\
\text { Deviation }\end{array}$ \\
\hline $\begin{array}{l}\text { Perputaran } \\
\text { Modal Kerja }\end{array}$ & 106 & $-44,02$ & 17,52 & 0,47 & 5,91 \\
$\begin{array}{l}\text { Perputaran } \\
\text { Piutang }\end{array}$ & 106 & 0 & 98,3 & 16,5 & 19,16 \\
$\begin{array}{l}\text { Perputaran } \\
\text { Persediaan }\end{array}$ & 106 & 0,51 & 49,2 & 5,73 & 8,64 \\
Profitabilitas & 106 & 0,24 & 31,61 & 7,42 & 5,47 \\
\hline
\end{tabular}

Variabel perputaran modal kerja memiliki nilai minimum $-44,02$, nilai maksimum 17,52, rata-rata (mean) 0,47 dengan standar deviasi sebesar 5,91. Standar deviasi yang lebih besar dari mean menunjukkan sebaran variabel data yang besar antaran perputaran modal kerja terendah dan tertinggi. Variabel perputaran piutang memiliki nilai minimum 0 , nilai maksimum 98,3 , ratarata (mean) 16,5 dengan standar deviasi 19,16. Variabel perputaran Persediaan memiliki nilai minimum 0,51 , nilai maksimum 49,2, rata-rata (mean) 5,73, dengan standar deviasi 8,64. Variabel profitabilitas memiliki niali minimum 0,24 , nilai maksimum 31,61, rata-rata (mean) 7,42 dengan standar deviasi 5,45.

Analisis Regresi Linear Berganda Model ini digunakan untuk mengetahui seberapa besar pengaruh variabel independen yaitu Perputaran modal kerja, 
perputaran piutang, dan perputaran Persediaan terhadap variabel dependen yaitu profitabilitas. Berdasarkan pengolahan data, maka diperoleh hasil sebagai berikut:

Tabel 2: Uji Regresi Linear Berganda

\begin{tabular}{lccc}
\hline Model & B & t & sig. \\
Konstanta & 6,472 & 8,235 & 0,000 \\
\hline Perutaran Modal Kerja & $-0,067$ & $-0,770$ & 0,442 \\
\hline Perputaran Piutang & 0,077 & 2,837 & 0,005 \\
\hline Perputaran Persediaan & $-0,051$ & 0,844 & 0,400 \\
\hline Adjusted R ${ }^{2}$ & 0,060 & & \\
F hitung & 3,236 & & \\
Sig. F & 0,025 & & \\
\hline Berdasam Sumber data Sekonder 2020 & & \\
\hline M
\end{tabular}

Hasil pengujian hipotesis pada tabel dengan Analisis Regresi Linear Berganda menghasilkan persamaan:

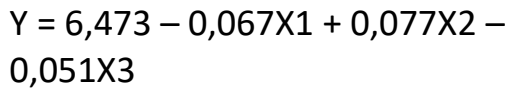

Berdasarkan hasil uji regresi menghasilkan nilai $\mathrm{F}$ hitung pada model penelitian sebesar 3.236 dengan taraf signifikansi 0,025 . Nilai signifikansi berada dibawah 0,05 yang menunjukkan bahwa variabel bebas dalam regresi ini secara bersama-sama mempengaruhi profitabilitas. Berdasarkan hasil regresi diketahui bahwa nilai koefisien determinasi (Adjusted $\mathrm{R}^{2}$ ) sebesar 0,060. Hal ini berarti $6 \%$ variabel profitabilitas dapat dijelaskan oleh variabel perputaran modal kerja, perputaran piutang, dan perputaran kas. Sedangkan sisanya $(100 \%-6 \%=94 \%)$ dijelaskan oleh faktor lain diluar model ini.

Pengujian Hipotesis Berdasarkan hasil pengujian hipotesis pertama, menunjukkan bahwa perputaran modal kerja berpengaruh negatif tetapi tidak signifikan terhadap profitabilitas perusahaan PT.Mandiri Mart, sehingga hipotesis pertama tidak terbukti kebenarannya.

Hal ini berarti bahwa semakin tinggi perputaran modal kerja maka akan menurunkan tingkat profitabilitas perusahaan. kondisi perputaran modal kerja dalam suatu perusahaan dipengaruhi oleh modal kerja (aktiva lancar dan utang lancar) dalam

\section{JQIM}

menghasilkan penjualan. Semakin tinggi volume penjualan yang dihasilkan maka modal kerja berputar semakin cepat sehingga modal dapat kembali keperusahaan yang disertai keuntungan yang tinggi pula, adanya keuntungan yang tinggi menyebabkan ROI perusahaan juga akan meningkat. Berpengaruh negatif tidak signifikan dikarenakan perusahaan belum menggunakan modal kerja secara efisien. Hal ini ditunjukkan dengan adanya tingkat penjualan yang tinggi akan menurunkan profitabilitas (ROI).

Berdasarkan hasil pengujian hipotesis kedua, menunjukkan bahwa Perputaran piutang berpengaruh positif signifikan terhadap Profitabilitas perusahaan PT.Mandiri Mart, sehingga hipotesis kedua terbukti kebenarannya.

Berdasarkan hasil pengujian hipotesis ketiga, menunjukkan bahwa Perputaran Persediaan berpengaruh negatif tetapi tidak signifikan terhadap profitabilitas perusahaan PT.Hang Mart, sehingga hipotesis ketiga tidak terbukti kebenarannya.

\section{KESIMPULAN}

Berdasarkan Berdasarkan hasil analisis data maka dapat disimpulkan bahwa secara parsial variabel perputaran modal kerja berpengaruh negatif tetapi tidak signifikan terhadap profitabilitas, variabel perputaran piutang berpengaruh positif signifikan terhadap Profitabilitas, variabel Perputaran Persediaan berpengaruh negatif tetapi tidak signifikan terhadap Profitabilitas. Hasil uji ketepatan model diperoleh nilai $\mathrm{F}$ hitungdengan $p$ value $0,025<0,05$ berarti model ini tepat digunakan untuk memprediksi pengaruh variabel bebas yaitu perputaran modal kerja, perputaran piutang, dan perputaran Persediaan terhadap variabel terikat (profitabilitas). Hasil koefisien determinasi (Adjusted $\mathrm{R}^{2}$ ) sebesar 0,060 . Hal ini berarti $6 \%$ variabel profitabilitas dapat dijelaskan oleh variabel Perputaran modal kerja, 


\section{JQIM}

perputaran piutang dan perputaran Persediaan, sedangkan sisanya $94 \%$ dijelaskan oleh variable lain yang tidak diteliti misalnya periode pengumpulan piutang dan ukuran perusahaan. oleh karena itu pada penelitian mendatang perlu mengembangkan variabel-variabel lain yang diperkirakan dapat mempengaruhi profitabilitas perusahaan.

\section{REFERENSI}

Agus Sartono, 1998, Manajemen Keuangan Edisi Ketiga, BPFE, Yogyakarta.

Agus Sartono, 1998, Manajemen Keuangan Teori dan Aplikasi Edisi Kedua, BPFE, Yogyakarta.

Bambang Riyanto, 2001, Dasar-dasar Pembelanjaan Perusahaan, BPFE, Yogyakarta.

I Made Dian Satriya dan Putu Vivi lestari, 2012, "Pengaruh Perputaran Modal Kerja Terhadap Profitabilitas Perusahaan", Jurnal Ekonomi dan Bisnis, Udayana, Bali.

Kasmir, 2011, Analisis Laporan Keuangan, Salemba Empat, Jakarta.

Kasmir, 2013, Analisis Laporan Keuangan, Jakarta: PT Rajagrapindo Persada.

Lutfi Jaya Putra, "Pengaruh Perputaran Modal Kerja Terhadap Profitabilitas Perusahaan (Studi Kasus: PT Indofood Sukses Makmur Tbk), Jurnal Ekonomi, Gunadarma, Depok.

Nike Ismiati, dkk., 2013, "Pengaruh Perputaran Modal Kerja Terhadap profitabilitas (Studi Kasus pada Perusahaan Manufaktur yang Terdaftar di Bursa Efek Indonesia), Jurnal Ilmu Administrasi Bisnis, Jember.

Rina Yuliani, "Pengaruh Perputaran Piutang terhadap Profitabilitas pada Perusahaan PT. Unilever Indonesia Tbk tahun 2005-2012”,
Jurnal Ekonomi dan Bisnis, Universitas Brawijaya, Malang. 